\title{
Being an academic dermatologist in Turkey: Young academic dermatologists' perspectives on dermatology
}

Türkiye'de akademik dermatolog olmak: Genç akademik dermatologların dermatoloji üzerine bakıș açıları

\author{
• Sezgi Sarıkaya Solak, ๑ Andaç Salman* \\ Trakya University Faculty of Medicine, Department of Dermatology and Venereology, Edirne, Turkey \\ *Marmara University School of Medicine, Department of Dermatology and Venereology, İstanbul, Turkey
}

\begin{abstract}
Background and Design: This study aims to examine the characteristics of young Turkish academic dermatologists and identify the positive and negative aspects of being an academic dermatologist from their perspectives.

Materials and Methods: A cross-sectional, electronic questionnaire was mailed to dermatologists who work as an assistant professor or faculty member of dermatology in a university or training and research hospital in Turkey. The questions were prepared to evaluate views of young academic dermatologists on academic dermatology.

Results: A total of 37 assistant professors and faculty members of dermatology responded to the survey. The top three reasons for pursuing an academic career and the most satisfying and pleasing aspects of academic life were the opportunity to teach, do research, and deal with complex diseases. Compensation was the least frequently (5.4\%) chosen reason to pursue an academic life. Insufficient time (70.3\%) was stated to be the most challenging aspect of research activities. The most cited issues respondents stated that they needed support or education were data analysis (78.4\%) and training abroad (67.6\%).

Conclusion: To our knowledge, this is the first study to evaluate academic dermatology in Turkey. We believe that the present study results provide insight into academic dermatology and might help increase the awareness of the dermatology residents who pursue an academic career.

Keywords: Academic, dermatology, Turkey

\section{Öz}

Amaç: Çalışmamız ülkemizdeki genç akademisyen dermatologların özelliklerini değerlendirmeyi ve onların gözünden dermatoloji alanında akademisyen olmanın olumlu ve olumsuz yönlerini incelemeyi amaçlamışır.

Gereç ve Yöntem: Kesitsel olarak planlanan çalısmamızda, Türkiye'de bir üniversite veya eğitim ve araştırma hastanesinde, dermatoloji alanında, doktor öğretim üyesi veya öğretim görevlisi olarak çalışan dermatologlara elektronik bir anket gönderilmiştir. Anket soruları genç akademisyen dermatologların, akademik dermatoloji hakkındaki görüșlerini değerlendirmek için hazırlanmıştır.

Bulgular: Çalışmamıza doktor öğretim üyesi ve öğretim görevlisi ünvanına sahip toplam 37 dermatoloji hekimi katılmıştır. Katılımcılar; akademisyenliği seçmelerinin en önemli nedenlerinin ve akademik yaşamın en tatmin edici yönlerinin, eğitim vermek, araştırma yapmak ve kompleks hastalıklarla uğraşmak olduğunu belirtmişlerdir. Maddi gelir, akademisyenliğin tercih edilmesinde en az etkili $(\% 5,4)$ neden olarak saptanmışıı. Araştırma yapmanın en zorlayıcı yönünün, araştırma faaliyetleri için yeterli zaman olmaması $(\% 70,3)$ olduğu öğrenilmiştir Katılımcılar, desteğe veya eğitime en çok intiyaç duydukları konuların, araştırma istatistiklerinin yapılması $(\% 78,4)$ ve yurtdışında eğitim tecrübesi $(\% 67,6)$ olduğunu ifade etmişlerdir.

Sonuç: Çalışmamız, bildiğimiz kadarıyla, Türkiye'de dermatoloji alanında akademisyenliği değerlendiren ilk çalş̧a özelliğini taşımaktadır. Çalışmamızın sonuçlarının, ülkemizde akademik dermatoloji hakkında bilgi sağladığına ve akademik hayata devam etmek isteyen dermatoloji hekimlerinin farkındalığını artırmaya yardımcı olabileceğine inanıyoruz.

Anahtar Kelimeler: Akademik, dermatoloji, Türkiye
\end{abstract}

Address for Correspondence/Yazışma Adresi: Sezgi Sarıkaya Solak MD, Trakya University Faculty of Medicine, Department of Dermatology and Venereology, Edirne, Turkey Phone: +90 2842357641 (1282) E-mail: sezgisarikaya@gmail.com Received/Geliş Tarihi: 08.04.2020 Accepted/Kabul Tarihi: 15.09.2020 ORCID: orcid.org/0000-0002-8572-8249 


\section{Introduction}

Academic medicine, classically, consists of three components: Education, research, and clinical practice ${ }^{1}$. Training the next generation of doctors who will meet society's health needs is one of the main tasks of academic medicine ${ }^{1,2}$. Clinical practice is an integral part of academic medicine as patients with severe, complicated, therapy-resistant, or rare diseases may seek care in academic institutions ${ }^{3}$. Besides, some patients seek care from academic clinicians because they believe they have more expertise and experience ${ }^{3,4}$. In addition to these components, research is a fundamental part of academia and contributes to the medical field ${ }^{5}$. Academic life is maintained by balancing these three components but carrying out these three responsibilities has some difficulties.

Over the past few decades, the number of academicians in medicine is reported to be decreasing worldwide ${ }^{1,6-8}$. Many studies investigating the causes of this decline are being conducted internationally ${ }^{1,9-11}$. This decline is also relevant to academic dermatology ${ }^{12-14}$. Previous reports have shown that dermatologists' academic interest is decreasing over time 14-16 $^{140}$

In recent years, an increasing number of articles about academic dermatology have been published ${ }^{12-17}$. However, no studies examine being an academic in dermatology in Turkey to our knowledge. This article will review the survey results of the assistant professors and faculty members in academic dermatology. We aimed to determine young academic dermatologists' demographic characteristics and identify the pros and cons of being an academic dermatologist from their perspective.

\section{Materials and Methods}

A cross-sectional, anonymous, and voluntary electronic questionnaire was mailed to dermatologists who work as an assistant professor or faculty member of dermatology in a university or training and research hospital in Turkey. The name and email lists of assistant professors and faculty members of dermatology were obtained from the Council of Higher Education Academic Search website ${ }^{18}$. Where online information was unavailable, telephone inquiry to the institution was performed. The questionnaire was sent by email, followed by a reminder email two weeks later. No individually identifiable data was collected.

The questionnaire consisted of three sections. The first section comprised 25 close-ended questions focusing on the following items: Demographic characteristics, interest in academic dermatology at the time of residency, reasons for choosing academic dermatology, training abroad during residency and academic life, academic workload, the most and least satisfying aspects of academic dermatology, and the subjects in which the academics need further support or training. The second part comprised 0-10 points response scales measuring the overall satisfaction on the following items; subspecialty, research opportunities, mentor support, compensation, and working environment. The last section comprised free-text responses for those who have anything to add to academic dermatology's positive and negative aspects. The study was approved by the Local Ethics Committee of Trakya University Faculty of Medicine (approval number: 22/38, date: 23.12.2019). Since it was a survey study, the patient consent form was not obtained.

\section{Statistical Analysis}

Data obtained from the questionnaires were analyzed with IBM SPSS Statistics version 24 . Numerical variables are shown as mean \pm standard deviation and categorical variables as percentages of the population.

\section{Results}

\section{Demographic of respondents}

Of the 73 assistant professors and faculty members of dermatology, 37 responded to our questionnaire, achieving a response rate of $50.6 \%$. Thirty (81.1\%) respondents were female, and seven (18.9\%) were male. The mean age of the respondents was 37 (range: 31-49) years. Thirty-four (91.9\%) respondents were married, and 28 (75.7\%) had one or more children. Thirty-two $(86.4 \%)$ of the participants were assistant professors. Most respondents (64.9\%) were working in a public university. The mean starting age of the academy was 35.1 years. Mean years in academic dermatology was 2.7 (range: 0-6) years. There were no differences according to the starting age of academic dermatology between male and female dermatologists. Characteristics of respondents are summarized in Table 1.

\section{The workload on education, research, and patient care}

Most respondents (89\%) had teaching tasks. Sixty percent of the teaching academics spent more than five hours for education during a week. The ratio of participants who had no or fewer than five publications during residency was $64.8 \%$, whereas those were $51.4 \%$ during academic life. Only four (10.8\%) and two (5.4\%) of the respondents had been abroad for training during his/her residency and academic career, respectively. The distribution of the number of patients seen during a week is shown in Figure 1a. Approximately one-third of the respondents $(n=12,32.4 \%)$ ran a subspecialty clinic (Figure $1 b$ ). The first three subspecialties were dermato-oncology, psoriasis, and bullous disease, respectively (Figure 1c). The most common reason for choosing their subspecialty was personal interest (75\%). Details on the workload of education, research, and patient care are given in Table 2.

\section{Views of academics on satisfying, pleasing, and challenging parts} of academic dermatology

Fourteen (37\%) respondents answered "yes" to whether they wanted to be an academic during the residency period. The top three reasons for pursuing an academic career were the opportunity to teach $(n=28$, $75 \%)$, doing research $(n=27,73 \%)$ and dealing with complex diseases $(n=20,54 \%)$. These three reasons were also the most satisfying and pleasing aspects of academic life. Compensation was the least frequently (5.4\%) cited reason to pursue an academic life. Insufficient time $(70.3 \%)$ was stated to be the most challenging aspect of research activities. The detailed findings are shown in Table 3. A 10-point numeric scale used to evaluate academics' satisfaction with research facilities, subspecialty, mentorship, compensation, and the working environment is shown in Figure 2.

\section{Discussion}

This study has demonstrated the characteristics, current states, and views of young academic dermatologists in Turkey. Although some findings of this study are predictable, we believe that our study might 
Table 1. Demographic features of young academic dermatologists

\begin{tabular}{|c|c|c|}
\hline & Number (\%) & $\begin{array}{l}\text { Mean } \pm(S D)- \\
\text { range }\end{array}$ \\
\hline Age & - & $37.7(31-49)$ \\
\hline Female & - & $37.7 \pm 3.8$ \\
\hline Male & - & $37.7 \pm 6.6$ \\
\hline \multicolumn{3}{|l|}{ Gender } \\
\hline Female & $30(81.1)$ & - \\
\hline Male & $7(18.9)$ & - \\
\hline \multicolumn{3}{|l|}{ Marital status } \\
\hline Single & $3(8.1)$ & - \\
\hline Married & 34 (91.9) & - \\
\hline \multicolumn{3}{|l|}{ Have a child/children } \\
\hline Yes & $28(75.7)$ & - \\
\hline No & $9(24.3)$ & - \\
\hline \multicolumn{3}{|l|}{ Academic rank } \\
\hline Assistant professor & $32(86.4)$ & - \\
\hline Faculty member & $5(13.7)$ & - \\
\hline \multicolumn{3}{|l|}{ Current institution } \\
\hline Public university & $24(64.9)$ & - \\
\hline Private/foundation university & $8(21.6)$ & - \\
\hline Training and research hospital & $5(13.5)$ & - \\
\hline \multicolumn{3}{|l|}{ Institution of residency } \\
\hline Public university & $25(67.6)$ & - \\
\hline Private/foundation university & $1(2.7)$ & - \\
\hline Research and training hospital & $11(29.7)$ & - \\
\hline Starting age of academy & - & $35.1(29-45)$ \\
\hline Female & - & $35.2 \pm 3.7$ \\
\hline Male & - & $35.0 \pm 5.2$ \\
\hline Years in academic dermatology & - & 2.7 \\
\hline $0-3$ years & $26(70.2)$ & - \\
\hline 4-6 years & $11(29.7)$ & - \\
\hline SD: Standard deviation & & \\
\hline
\end{tabular}
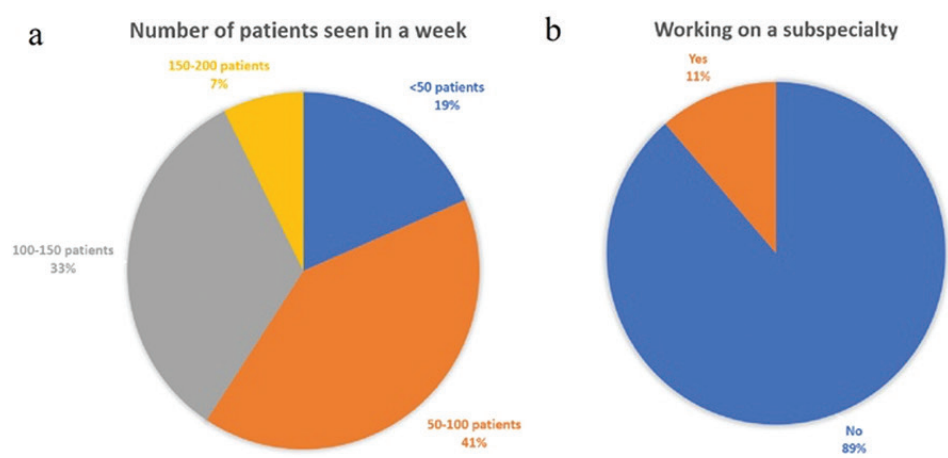

recognize the current state and unmet needs of academic dermatology in Turkey from the young dermatologists' perspective.

The number of female dermatologists in Turkey exceeds the number of male dermatologists for a long time. Currently, approximately $70 \%$ of the dermatologists in Turkey are female ${ }^{19}$. As a reflection of this fact, the vast majority (81\%) of the respondents in our study were women. It can be expected that dermatologists who are not married or without children are more likely to pursue an academic career. However, as our study demonstrated that most of the young academic dermatologists were married and had children. These results could be explained by the fact that the average age of the respondents corresponds to the average age of marriage in Turkish customs.

In the last 15 years, dermatology has become one of the most preferred specialties among medical graduates in Turkey and other countries ${ }^{15,16,20-22}$. Over the last few years, only successful medical graduates who get the highest scores in the specialty examination enter Turkey's dermatology residency. However, our study demonstrated, their interest did not persist in academic life. Even among current academic dermatologists, only 37\% wanted to be an academic during their residency period. In a study conducted among Turkish dermatology residents in 2009, the frequency of participants who want to pursue academic life was slightly higher (47\%). The desire to be an academic decreased as the year of residency increased ${ }^{23}$. Similarly, low interest in academic dermatology was reported in many previous studies conducted in other countries ${ }^{12-16,20,21,24}$. Some important reasons are reported to be low income, lack of role models and career guidance, insufficient time for academic activities, lack of autonomy, and growing interest in cosmetic dermatology 12-16,20,21,24. Although our results may reflect the low interest in academic dermatology, future studies that include residents of dermatology, graduates of dermatology, and nonacademic dermatologists are needed to assess academic interest more accurately.

The number of participants' publications during their residency $(64.8 \%$ had no or fewer than five publications) and academic career was low. Since the current study included only academics, an even lower number of publications during residency might be expected if all residents were considered. Although most of the participants were at the beginning of their academic career (mean years in academic dermatology was 2.7), the number of publications during academic life was still low. We think that increased encouragement and support from mentors or senior

C Subspecialty

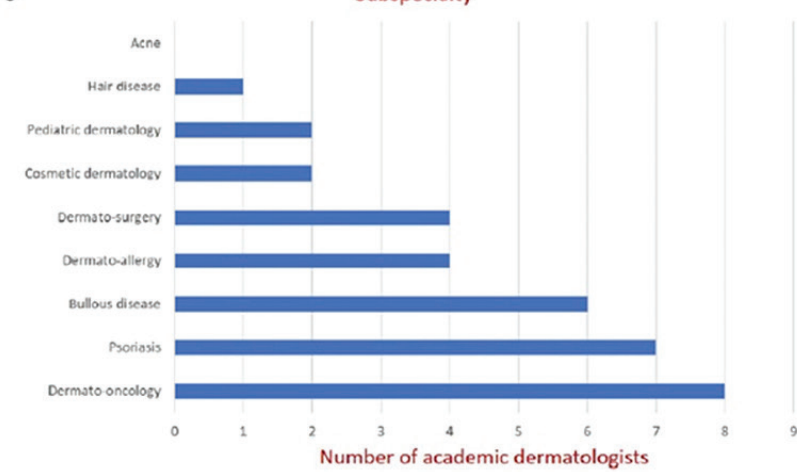

Figure 1. a) The distribution of the number of patients seen during a week. b) Working on a subspecialty clinic. c) The distribution of the subspecialty clinics 
Table 2. Workload in patient care, education, and research

\begin{tabular}{|c|c|}
\hline & Number (\%) \\
\hline \multicolumn{2}{|l|}{ Teaching medical students } \\
\hline Yes & $33(89.2)$ \\
\hline No & $4(10.8)$ \\
\hline \multicolumn{2}{|c|}{ Hours spent for teaching during a week (33 academics) } \\
\hline$<5$ hours & $13(39.3)$ \\
\hline 5-10 hours & $11(33.3)$ \\
\hline$>10$ hours & $9(27.2)$ \\
\hline \multicolumn{2}{|l|}{ Training abroad } \\
\hline During residency & $4(10.8)$ \\
\hline During academic life & $2(5.4)$ \\
\hline \multicolumn{2}{|l|}{ Number of publications during residency } \\
\hline None & $7(18.9)$ \\
\hline $1-5$ & $17(45.9)$ \\
\hline $5-10$ & $9(24.3)$ \\
\hline$>10$ & $4(10.8)$ \\
\hline \multicolumn{2}{|c|}{ Number of publications during academic career } \\
\hline Less than 5 & $19(51.3)$ \\
\hline $5-10$ & $2(5.4)$ \\
\hline $10-15$ & $6(16.2)$ \\
\hline$>15$ & $10(27)$ \\
\hline \multicolumn{2}{|l|}{ Reason to choose subspecialty* (12 academics) } \\
\hline Personal interest & $4(33.3)$ \\
\hline Needs of the department & $3(25.0)$ \\
\hline Personal interest + needs of the department & $5(41.6)$ \\
\hline \multicolumn{2}{|l|}{ Dermatology Board Certification } \\
\hline Turkish Board of Dermatology and Venereol & $5(13.5)$ \\
\hline European Board of Dermatology and Venereol & $1(2.7)$ \\
\hline None & $31(83.8)$ \\
\hline
\end{tabular}

faculty members beginning from the residency period might help gain experience for all residents in research and publishing and thus form a sound basis for a more productive academic life for those who pursue an academic career.

Teaching and doing research were the top two factors for pursuing academic dermatology and the top two satisfying and pleasing aspects of academic life. These results may be related to the personal traits of academic dermatologists. This was eloquently described by a young academic dermatologist who commented: "Teaching and doing research is a passion." These factors have been shown to have a strong influence on the career decisions of academic dermatologists in also previous studies ${ }^{12,15}$.

Dealing with complex diseases was another reason for pursuing academic dermatology and satisfying and pleasing aspect of academic life. In Turkey, the referral chain system is not obligatory in health care. Consequently, dermatologists working in secondary health institutions see many patients and may not devote enough time to complex patients. Although speculative, this could be explained with dermatologists who are ambitious in dealing with complex diseases prefer to be an academic as they can spend more time for patient consultations. Supporting this speculation, seeing a smaller number of patients, was another reason to pursue academic dermatology.

Endorsement by the head of the academic dermatology departments was one of the leading reasons academic dermatologists pursue an academic life. This may be an expected result as heads of academic departments desire dermatologists keen on academic life. The heads of departments probably know the high academic performance of the endorsed individuals, so they support and encourage these young dermatologists to work as academics.

Based on young academics' free-text responses, one of the most emphasized satisfying and pleasing aspects of academic life was a continuous learning experience. A young academic dermatologist commented: "In academic settings, we have to continue reading and searching, which makes us learn something new every other day.
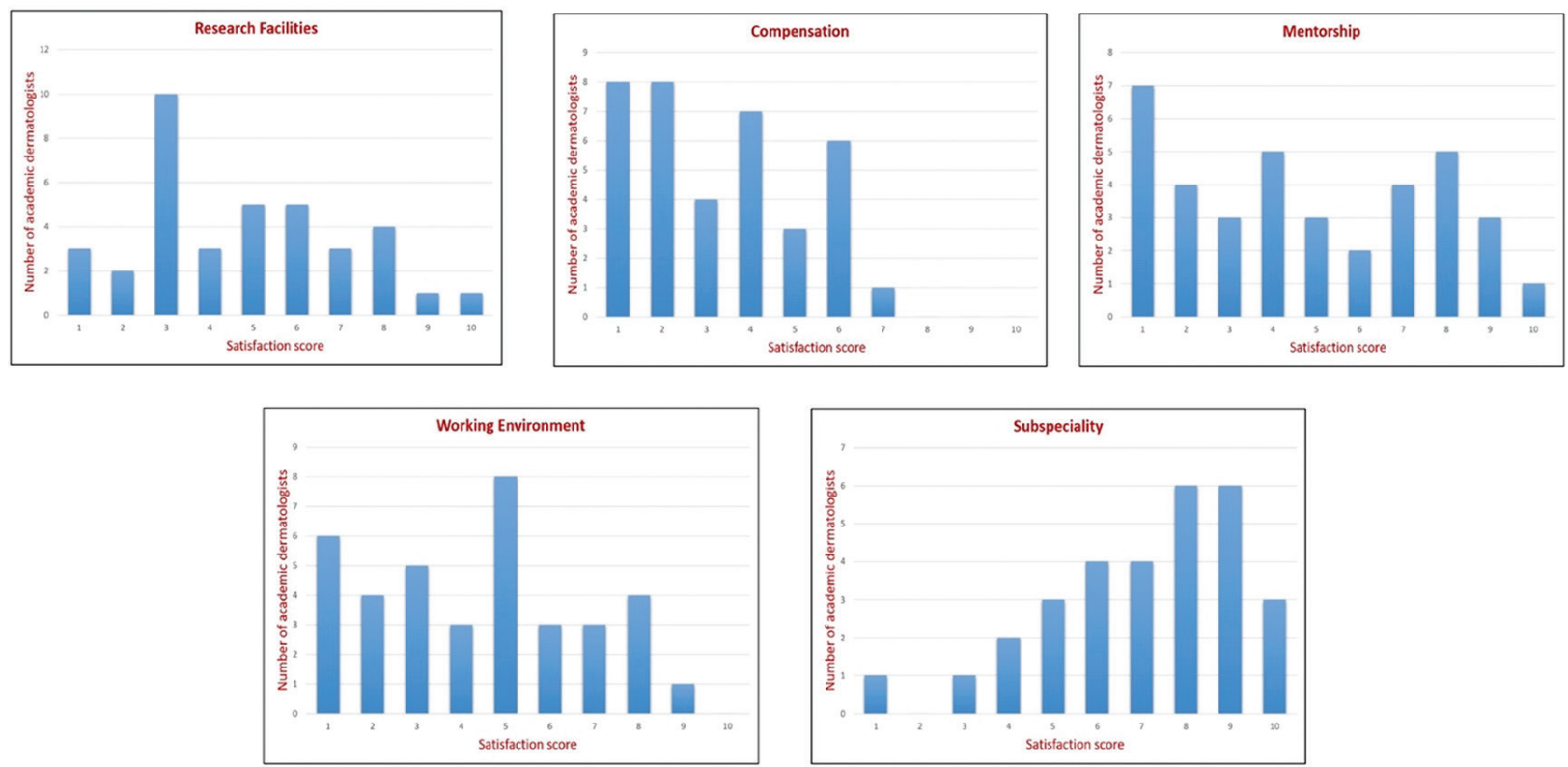

Figure 2. Satisfaction scores of academics using a 10-point numeric scale 
Table 3. Young academic dermatologists' views on satisfying, pleasing, and challenging parts of academic dermatology

Survey question

Number (\%)

"Did you want to be an academic during the dermatology residency?"

\begin{tabular}{|l|l|}
\hline Yes & $14(37.8)$ \\
\hline No & $5(13.5)$ \\
\hline I did not have a clear decision & $12(32.4)$ \\
\hline I did not have any opinion & $6(16.2)$ \\
\hline
\end{tabular}

"What are your reasons for choosing academic dermatology?"*

\begin{tabular}{|l|l|}
\hline Teaching & $28(75.7)$ \\
\hline Doing research & $27(73)$ \\
\hline Dealing with complex diseases & $20(54.1)$ \\
\hline $\begin{array}{l}\text { Endorsement by the head of the academic } \\
\text { dermatology departments }\end{array}$ & $12(32.4)$ \\
\hline Working on a subspecialty in dermatology & $11(29.7)$ \\
\hline Academic rank & $11(29.7)$ \\
\hline Seeing fewer patients & $11(29.7)$ \\
\hline Being influenced by an academic role model & $9(24.3)$ \\
\hline Familial issues & $6(16.2)$ \\
\hline City & $5(13.5)$ \\
\hline Leaving the compulsory service & $4(10.8)$ \\
\hline Compensation & $2(5.4)$ \\
\hline Colleagues & $1(2.7)$ \\
\hline
\end{tabular}

"What are the satisfying and pleasing aspects of the academic life?"*

\begin{tabular}{|l|l|}
\hline Doing research & $29(78.4)$ \\
\hline Teaching & $25(67.6)$ \\
\hline Dealing with complex patients & $19(51.4)$ \\
\hline Working on a specialty in dermatology & $13(35.1)$ \\
\hline Seeing fewer patients & $11(29.7)$ \\
\hline Having an academic rank & $6(16.2)$ \\
\hline Other & $1(2.7)$ \\
\hline
\end{tabular}

"What are the difficulties/challenges that you face in research activities?"*

\begin{tabular}{|l|l|}
\hline Insufficient time & $26(70.3)$ \\
\hline Data analysis (statistics) & $21(56.8)$ \\
\hline Publishing the article & $20(54.1)$ \\
\hline Finding research funding & $19(51.4)$ \\
\hline Planning the research & $12(32.4)$ \\
\hline Writing the article & $11(29.7)$ \\
\hline Applying to the ethics committee & $11(29.7)$ \\
\hline $\begin{array}{l}\text { "In which issues do you think you need support/education in } \\
\text { academic life?"* }\end{array}$ \\
\hline Data analysis (statistics) & $29(78.4)$ \\
\hline Training abroad in dermatology & $25(67.6)$ \\
\hline Planning a research & $18(48.6)$ \\
\hline Academic English & $17(45.9)$ \\
\hline Writing an article & $14(37.8)$ \\
\hline Presentation techniques & $11(29.7)$ \\
\hline Medical equipment (digital dermoscopy, microscopy, etc) & $1(2.7)$ \\
\hline *Multiple choices possible & \\
\hline
\end{tabular}

Thus, job satisfaction is maintained." Another respondent summed up his view on the learning process in academia: "You stay up to date." Compensation was the least frequently chosen reason to pursue an academic life. Moreover, none of the respondents cited "compensation" as a satisfying and pleasing aspect. Similarly, a survey from the United States $^{12}$ identified that academics never listed compensation as a motivating factor by academics. Moreover, the low financial reward was one reason for not choosing academic dermatology in the United Kingdom ${ }^{24}$. Furthermore, low income has been identified as the most common reason for leaving academia in the United States previously ${ }^{14}$. Dogra ${ }^{21}$ emphasized there is growing interest in cosmetic dermatology and private practice due to the faster and greater income potential, which may serve as a negative factor to pursue academic dermatology. Although no data is comparing the incomes of dermatologists in academia and private practice in Turkey, the perception that academic dermatologists have lower incomes than those in private practice is quite common. Conducting studies that evaluate the compensation discrepancies between academics and non-academics will provide data on this critical factor, which seems to play an important role in pursuing an academic career.

Young academics have cited "insufficient time" as the most challenging aspect of research activities, which was also frequently reported previously ${ }^{13,14}$. In the open comments section of our questionnaire, many respondents agreed that they have to spend too much time on patient care due to the performance system, leaving them little time for other academic work. This result is in line with a previous study reported by Altındiş et al. ${ }^{25}$ conducted among Turkey's medical academics. In their study, $75 \%$ of the respondents stated that they did not have enough time for research activities due to the performance system in health care. Insufficient time also reduces the motivation of academic dermatologists. An academic dermatologist stated: "Because of seeing so many patients, I cannot spend time on doing research, and it really makes me unhappy. This exhausting tempo affects us quite negatively." Another respondent commented: "I do not think academics can really focus on research activities, especially in medical faculties in affiliation with the Ministry of Health. The system is focused on patient care. We do not have any support for research activities." Another dermatologist summarized the academic career's negative aspects: "There is no balance between research/education and patient care."

Data analysis, publishing the article, and getting funding for research were other common challenges in research activities. Dermatology associations or medical faculty program directors may organize more courses or workshops on these subjects to promote young academic dermatologists' success. Another way to eliminate those and other challenges faced by young academics (planning the research, writing the article, and applying to the ethics committee) is to implement mentorship programs in dermatology. In the United States, an increasing number of academic dermatology centers have mentorship programs in residency ${ }^{26}$. It is well-recognized that mentoring is one of the essential factors in academic medicine for many issues such as career preparation, research productivity, personal development, networking, and retention of academics ${ }^{26-28}$. Reck et al. ${ }^{16}$ have reported that half of the residents who lost interest in academic dermatology attributed the loss to the lack of mentors.

Similarly, Aquino et al. ${ }^{29}$ suggested that residents' mentorship opportunities to may encourage graduates to become academic 
dermatologists. Mentoring programs are not only crucial for residents but young academics as well ${ }^{30}$. In Turkey, although some young academics have spontaneous mentors in their departments, not all academics have someone they consider as a mentor. Our study demonstrated, more than half of the participants (56\%) had a low level of satisfaction with mentoring. Developing mentorship programs for both residents and young academic dermatologists may be a good step for the professional development of academic dermatology in Turkey. A remarkable number of respondents (67\%) stated they need support in training abroad. Although the Turkish Association of Dermatology offers scholarships for observership opportunities in foreign countries ${ }^{31}$, the present study demonstrated only two (5\%) out of 37 young academic dermatologists have been abroad for medical experience. This may be related to the lack of mentors to guide and encourage young academics. Therefore, in addition to the present scholarships, the abovementioned mentorship programs organized by national societies may also be an effective way to support training abroad.

\section{Study Limitations}

Our survey study has many limitations. First, there is potential nonresponse bias due to the $50 \%$ response rate. Second, this study has a cross-sectional design and does not follow changes in academics' view over time. Finally, because we aimed to explore academic dermatology from the perspective of young academics, this study's results might not be generalized to whole academic dermatology in Turkey. Future studies, including all academic ranks, should be conducted to assess the advantages and disadvantages of academic dermatology.

\section{Conclusion}

Several important conclusions can be drawn from the results of the present study. Teaching and doing research were the most common reasons for pursuing academic dermatology. These factors were also the most satisfying aspects of academic life. Compensation was the least influential factor to choose an academic career. In line with this finding, satisfaction rates of compensation were very low. The most frequently cited difficulty was insufficient time for research activities. We believe that the present study results provide insight into academic dermatology and might help increase the awareness of the dermatology residents who pursue an academic career.

Acknowledgments: We would like to thank Prof. Dr. Tülin Ergun and Prof. Dr. Dilek Seçkin Gençosmanoğlu for inspiring this study by including this topic in the scientific program of the $28^{\text {th }}$ National Dermatology Congress.

\section{Ethics}

Ethics Committee Approval: The study was approved by the Local Ethics Committee of Trakya University Faculty of Medicine (approval number: 22/38, date: 23.12.2019).

Informed Consent: Since it was a survey study, the patient consent form was not obtained.

Peer-review: Externally and internally peer-reviewed.

\section{Authorship Contributions}

Surgical and Medical Practices: S.S.S., A.S., Concept: S.S.S., A.S., Design: S.S.S., A.S., Data Collection or Processing: S.S.S., A.S., Analysis or Interpretation: S.S.S., A.S., Literature Search: S.S.S., A.S., Writing: S.S.S., A.S.
Conflict of Interest: No conflict of interest was declared by the authors.

Financial Disclosure: The authors declared that this study received no financial support.

\section{References}

1. International Working Party to Promote and Revitalise Academic Medicine. ICRAM (the International Campaign to Revitalise Academic Medicine): agenda setting. BMJ 2004;329:787-9.

2. Schroeder SA, Zones JS, Showstack JA: Academic medicine as a public trust. JAMA 1989;262:803-12.

3. Christmas C, Durso SC, Kravet SJ, Wright SM: Advantages and challenges of working as a clinician in an academic department of medicine: academic clinicians' perspectives. J Grad Med Educ 2010;2:478-84.

4. Junod Perron N, Favrat B, Vannotti M: Patients who attend a private practice vs a university outpatient clinic: how do they differ? Swiss Med Wkly 2004;134:730-7.

5. Harman G: Research and scholarship. In: Forest J, Altbach P, eds. International Handbook of Higher Education. Dordrecht: Springer 2006;309-28.

6. Mashar M, Kilgour J, Nanapragasam H, Lipworth S: Academic medicine: the continuing challenges. Clin Teach 2020;17:81-5.

7. Kosik RO, Tran DT, Fan AP, et al: Physician Scientist Training in the United States: A Survey of the Current Literature. Eval Health Prof 2016;39:3-20.

8. Ley TJ, Rosenberg LE. The physician-scientist career pipeline in 2005: build it, and they will come. JAMA 2005;294:1343-51.

9. UK Clinical Research Collaboration, Modernising Medical Careers. Medically and dentally qualified academic staff: Recommendations for training the researchers and educators of the future. Report of the Academic Careers Sub-Committee of Modernising Medical Careers and the UK Clinical Research Collaboration. London: UK Clinical Research Collaboration, Modernising Medical Careers 2005.

10. Sheridan DJ. Reversing the decline of academic medicine in Europe. Lancet 2006;367:1698-701.

11. Simpkin AL, Chang Y, Yu L, Campbell EG, Armstrong K, Walensky RP: Assessment of job satisfaction and feeling valued in academic medicine. JAMA Intern Med 2019;179:992-4.

12. Morales-Pico BM, Cotton CC, Morrell DS: Factors correlated with residents' decisions to enter academic dermatology. Dermatol Online J 2016;22: 13030/qt7295783b.

13. Resneck JS Jr, Tierney EP, Kimball AB: Challenges facing academic dermatology: survey data on the faculty workforce. J Am Acad Dermatol 2006;54:211-6.

14. Loo DS, Liu CL, Geller AC, Gilchrest BA: Academic dermatology manpower: issues of recruitment and retention. Arch Dermatol 2007;143:341-7.

15. Kia KF, Gielczyk RA, Ellis CN: Academia is the life for me, I'm sure. Arch Dermatol 2006;142:911-3.

16. Reck SJ, Stratman EJ, Vogel C, Mukesh BN: Assessment of residents' loss of interest in academic careers and identification of correctable factors. Arch Dermatol. 2006;142:855-8.

17. Freiman A, Barzilai DA, Barankin B, Natsheh A, Shear NH: National appraisal of dermatology residency training: a Canadian study. Arch Dermatol 2005;141:1100-4.

18. Akademik.yok.gov.tr [Internet] Yüksek Öğretim Akademik Arama. Available from: https://akademik.yok.gov.tr/AkademikArama/

19. Personal communication. (Turkish Society of Dermatology, 27 December 2019)

20. Wu JJ, Ramirez CC, Alonso CA, Mendoza N, Berman B. Tyring SK: Dermatology residency program characteristics that correlate with graduates selecting an academic dermatology career. Arch Dermatol 2006;142:84550.

21. Dogra S: Fate of medical dermatology in the era of cosmetic dermatology and dermatosurgery. Indian J Dermatol Venereol Leprol 2009;75:4-7. 
22. Cengiz FP, Kemeriz F, Emiroglu N, Meydan MC. Dermatology residents' opinions: problems and proposals of their solutions in residency training Turk J Dermatol 2014;2:88-94

23. Yılmaz S, Baysal Akkaya V: Problems and proposals of their solutions in dermatology residency training. A survey of residents' opinions in Turkey. Turkderm 2009;43:10-4.

24. Tso S: Potential barriers to pursuing a career in academic dermatology. Br J Dermatol 2016;175:222-3.

25. Altındiş S, Dönmez TB, Aslan FG, Altındiş M: The barriers for scientific work, project, patents and innovation for medical academicists. J Biotechnol and Strategic Health Res 2017;1:24-30.

26. Donovan J: A survey of dermatology residency program directors' views on mentorship. Dermatol Online J 2009;15:1.
27. Sambunjak D, Straus SE, Marusić A: Mentoring in academic medicine: a systematic review. JAMA 2006;296:1103-15.

28. Ramanan RA, Phillips RS, Davis RB, Silen W, Reede JY: Mentoring in medicine: Keys to satisfaction. Am J Med 2002;112:336-41.

29. Aquino LL, Wen G, Wu JJ: Factors affecting the pursuit of academic careers among dermatology residents. Cutis 2015;95:231-6.

30. Sperduto AL, McKee MJ, DeLong LK, Veledar E, Chen SC: Describing the state of mentoring in academic dermatology. JAMA Dermatol 2013;149:486-8.

31. Turkdermatoloji.org.tr [Internet] Türk Dermatoloji Derneği [cited 2019 Dec 26] Available from: http://www.turkdermatoloji.org.tr 